\title{
Clinical researchers at odds
}

\section{Washington}

A FEDERAL appeals court has written the latest chapter in a bitter dispute over plagiarism between a former faculty member of Albert Einstein College of Medicine in New York and her mentor, now vice-chairman of nuclear medicine at the medical school. A three-judge panel overturned a lower court's ruling, and declared that Leonard Freeman violated copyright law when he put his name on a document prepared by Heidi Weissmann, but Freeman's attorneys have appealed against the latest decision. The case threatens to drag on.

Told one way, there seems little doubt that Freeman misappropriated Weissmann's work. In August 1987, Freeman was invited to present work on liver imaging in a review course at Mount Sinai School of Medicine in New York. Freeman took a syllabus prepared by Weissmann for a similar course sponsored by the Radiological Society of North America in 1985, deleted Weissmann's name from the manuscript and put his in its place, and changed the title from "Hepatobiliary Imaging" to "Gastrointestinal Nuclear Medicine Hepatobiliary Imaging". The same syllabus appeared in a book published in Taiwan under Freeman's name after a symposium in December 1986 in the Republic of China.

But the case can also be read differently. Weissmann and Freeman began their association when she was a resident at Einstein in 1977, and had collaborated on liver-imaging work since 1980. After finishing her residence, Weissmann became a faculty member at Einstein, working in Freeman's division.

The 1985 syllabus used by Weissmann was largely drawn from previous versions of the syllabus which were jointly produced, but which differed in some references, illustrations and some new text. Furthermore, when Weissmann filed her suit to prevent Freeman from presenting the syllabus at Mount Sinai, she was in the midst of a lawsuit accusing Einstein of sexual discrimination over issues of salary and sabbatical leave.

A district court judge in New York agreed with Freeman's contention that the syllabus was a product of collaborative research, and a continually evolving 'stock' piece to be used when either was called upon to teach a course in hepatobiliary imaging techniques. The judge ruled that Freeman should be considered a joint author of the syllabus, and therefore could not be guilty of violating copyright of it. He also ruled that Weissmann's modifications to the 1985 syllabus were insufficient to support separate copyright protection and that, even if Freeman was not considered a joint author of the sylla- bus, his intended use of the document fell under the 'fair use' doctrine as it was intended for teaching and not personal profit.

But the appeals court saw things differently. In a 2-1 decision, the court ruled that Freeman's use of the syllabus was a violation of copyright. The majority opinion states that the decision of the lower court "stands copyright law on its head" by concluding that joint authorship of prior work "automatically makes the two joint authors co-owners of the derivative work". The court goes on to state that originality is rightly prized in law, and alludes to Dostoevsky's example in The Idiot that a person's worth in revolutionary Russia "did not depend so much on money or position as it did on one's originality". The appeals court also ruled that, although he did not stand to gain financially from the copyright infringement, Freeman did gain in stature professionally by passing Weissmann's work off as his own.

Einstein and Montefiore Medical Center, where both worked, have been firmly behind Freeman throughout the dispute. Part of Freeman's legal costs have been met by his employer. An open letter from Montefiore's president Spencer Foreman following the lower court's ruling last May declared that the "Federal District Court has completely vindicated our colleague Leonard M.Freeman", and refers to Weissmann as "a former Montefiore employee and former student", rather than as a former faculty member. The letter ends with "I know you are all as pleased as I am with the decision reached by the federal court".

Weissmann is now out of work. The medical school maintains that she resigned when she failed to return to work after a sabbatical which ended in September 1987. Weissmann says she was fired because when she tried to go to her office in August of that year, days after taking legal steps to prevent Freeman from handing out the syllabus at Mount Sinai, hospital security guards confronted her and demanded that she hand over her office keys. Freeman, meanwhile, has been promoted to vice-chairman of his department.

Freeman says the dispute should never have gone to court. Weissmann says she by-passed university mechanisms for resolving disputes in the copyright case because she did not think the university would give her case adequate attention.

Einstein has had a poor track record in its attitude towards female faculty. It has been the object of a class action suit filed in the 1970s alleging sexual discrimination on salaries that has still not been settled. Eugene Girden, a lawyer for Freeman,

\section{Sterilization protests}

\section{Munich}

A PROPOSED new law that would make it legal to sterilize people judged mentally incompetent without their consent has prompted a vigorous protest in West Germany from those who fear the law might some day be used to justify enforced sterilizations of a broader class of people.

The provisions on sterilization are part of an otherwise welcome reform of the rights of mentally disabled people. The legislation would ban the sterilization of minors, and has been well received on that account across the political spectrum, especially because of its emphasis on counselling and support for people unable to speak for themselves. But critics say that the legislation also contains a potentially dangerous loophole that might at some future stage be widened by allowing the sterilization of adults who are mentally incompetent.

Hitherto, up to 1,000 sterilizations a year have been carried out in West Germany on people - minors and adults - deemed legally incapable of handling their own affairs. Many of these sterilizations are done at the request of parents of mentally handicapped children. Under West German law, incapacitated people have had no legal recourse against the procedure.

The new legislation permits the sterilization of people who do not specifically object in cases where pregnancy would create an "emergency situation". Any objection on the part of the person in question would result in the cancelling of the sterilization.

The Green Party, a judges' organization and handicapped rights groups have protested against the law and are preparing to fight it in parliament. The current law, which dates back to 1900 , deprives mentally incompetent adults of all rights, leaving them the equivalent of a child in legal terms. The new law was meant to be a landmark in a series of social programmes that have been staggering through parliament in recent months. The proposal has been sent to both houses of the West German parliament for discussion. The government hopes to gain approval for the law by the end of this year. Steven Dickman

says it is ironical that Weissmann is suing Freeman, as he was one of her strongest supporters at the university.

Weissmann's case has been taken up by the National Coalition for Universities in the Public Interest, a Washington watchdog group, which intends to file new charges in Weissmann's discrimination suit still pending in New York State court. Leonard Minsky, the coalition's executive director, argues that Weissmann's experience is just one of a series of cases involving plagiarism, sexual discrimination and conflict of interest in US universities.

Joseph Palca 